\title{
TOURIST DEVELOPMENT FOR NATURE TOURISM THE EXAMPLE OF NATURA 2000 AREAS IN THE VOIVODESHIP OF LUBLIN
}

DOI: http://dx.doi.org/10.18509/GBP.2016.45
UDC: $338.48-6: 502 / 504(438)$

\section{MSc Monika Kordowska}

University of Warsaw, Poland

\begin{abstract}
Natura 2000 sites were created for the protection of different habitat types and species of plants and animals which are considered valuable and endangered in the whole Europe. A great variety of species leads to high natural values necessary for nature tourism. Their conservation status doesn't limit the possibilities of using them for tourism. Obviously it is necessary to adhere regulations and take care of the natural environment. The effectiveness of the protection depends on the character of tourism infrastructure. It includes: accommodation, food and beverage, transport and supporting facilities.

The purpose of this article is to discuss condition of tourist development within Special Protection Areas for birds Natura 2000 in the Voivodeship of Lublin. The tourist facilities were evaluated using both qualitative (literature analysis, field observations, author's participation in nature tours) and quantitative (databases of Central Statistical Office of Poland, Nature 2000 Standard Data Form, digital and paper maps analysis) methods. Using two types of methods allows to see how area suitable are facilities for both tourist use and nature protection. This is very important because appropriate development crucial for proper contact with nature.
\end{abstract}

Keywords: Voivodeship of Lublin, Natura 2000, tourism infrastructure, nature tourism

\section{INTRODUCTION}

Nature protection according to The Act of 16 April 2004 on Nature Protection [1] means the maintenance, proper use, restoration of natural ecosystems and their components, especially: wild plants, animals and natural habitats. The aim of conservation is to protect biodiversity, to maintain ecological processes, to restore the proper state of natural components and also to develop people's commitment to nature.

In the European Union these goals are implemented by Natura 2000 network. In Poland it is the youngest form of environmental protection introduced to the state legislation. The first areas were created in 2004 year, followed by the network expansion in 2007, 2008 and 2011. The legal basis of Natura 2000 are two European Union directives commonly called the Birds Directive ${ }^{3}$ and the Habitats Directive ${ }^{4}$. Basing on them the Natura 2000 sites include two types of areas: Special Areas of Conservation (SACs) and Special Protection Areas for birds (SPAs). Currently, the both types occupy

\footnotetext{
${ }^{3}$ Directive 2009/147/EC on the conservation of wild birds

${ }^{4}$ Directive 92/43/EEC of 21 May 1992 on the conservation of natural habitats and of wild fauna and flora
} 
about $20 \%$ of the terrestrial area of Poland (more then $68000 \mathrm{~km}^{2}$ ). The Nature 2000 network in Poland consists of 849 SACs and 145 SPAs.

Distinguish Natura 200 from such forms of protection as national parks or strict reserves, are the possibilities of their economic use. According to the article 33, point 1 The Act of 16 April 2004 on Nature Protection [1], within the Natura 2000 areas only activities that destroy protected habitats and species forbidden. One way of using these areas is tourism and recreation [2].

One of the most environmentally friendly forms of tourism is nature tourism. It is also known as green tourism, alternative tourism, soft tourism, sustainable tourism, responsible tourism or ecological tourism [3][4][5]. Various definitions of this phenomenon can be found. Kowalczyk [5] describe nature tourism as the type of tourism, where tourists focus on the exploration of abiotic (geotourism) and biotic (plants and animals). According to some authors, this activity should take place in the highly natural environment [6] or almost exclusively in the protected areas [4].

Areas visited by tourists should be properly developed in order to avoid the of negative impact of tourism on protected plants, animals and habitats. For this reason the Natura 2000 areas require eco-friendly tourist infrastructure. It includes: accommodation, food and beverage, transport and supporting facilities. This way tourism within they Natura 2000 can be controlled. Moreover, the appropriate infrastructure facilitate contact with nature and makes the place more attractive [7].

The aim of this study is to describe infrastructure for nature tourism within SPAs, taking as the example one of Polish administrative regions.

\section{RESEARCH AREA}

The Voivodeship of Lublin is one of the 16 voivodeships in Poland. Geographical diversity of the region is reflected by the fact, that it is situated on the border of three European megaregions: Eastern European Lowland, Non-Alpine Central Europa and Carpathian Region [8]. For this reason the Voivodeship of Lublin is characterised by high natural values associated with bio- and geodiversity.

69 the Natura 2000 areas exist in the voivodeship, including 23 SPAs. They cover an area 334162 ha, which constitutes $13,3 \%$ of the total area of the voivodeship. Some of them are located on the territory of more than one voivodeship. In this study the SPAs that are located within the Voivodeship of Lublin in at least $50 \%$ are considered. These are 20 SPAs (Figure 1).

The research areas are located unevenly, mainly in the southern part of the voivodeship. The Natura 2000 areas differ in their area (ha), habitat types present on the site, site protection status and relation with other sites and nature value. Most of them interfere with the national parks (Poleski and Roztoczański National Park), landscape parks, nature reserves, protected landscape areas and ecological sites.

All selected areas are characterized by high ornithological values. For example Chełm Calcareous Marshes are the third and the most numerous breeding area of Aquatic Warbler in Poland. Tyśmienica Valley with the complex of fish ponds is recognised as one the most important refugees of wetland birds. Furthermore in selected areas we can see the spotted souslik and also the European pond turtle. 


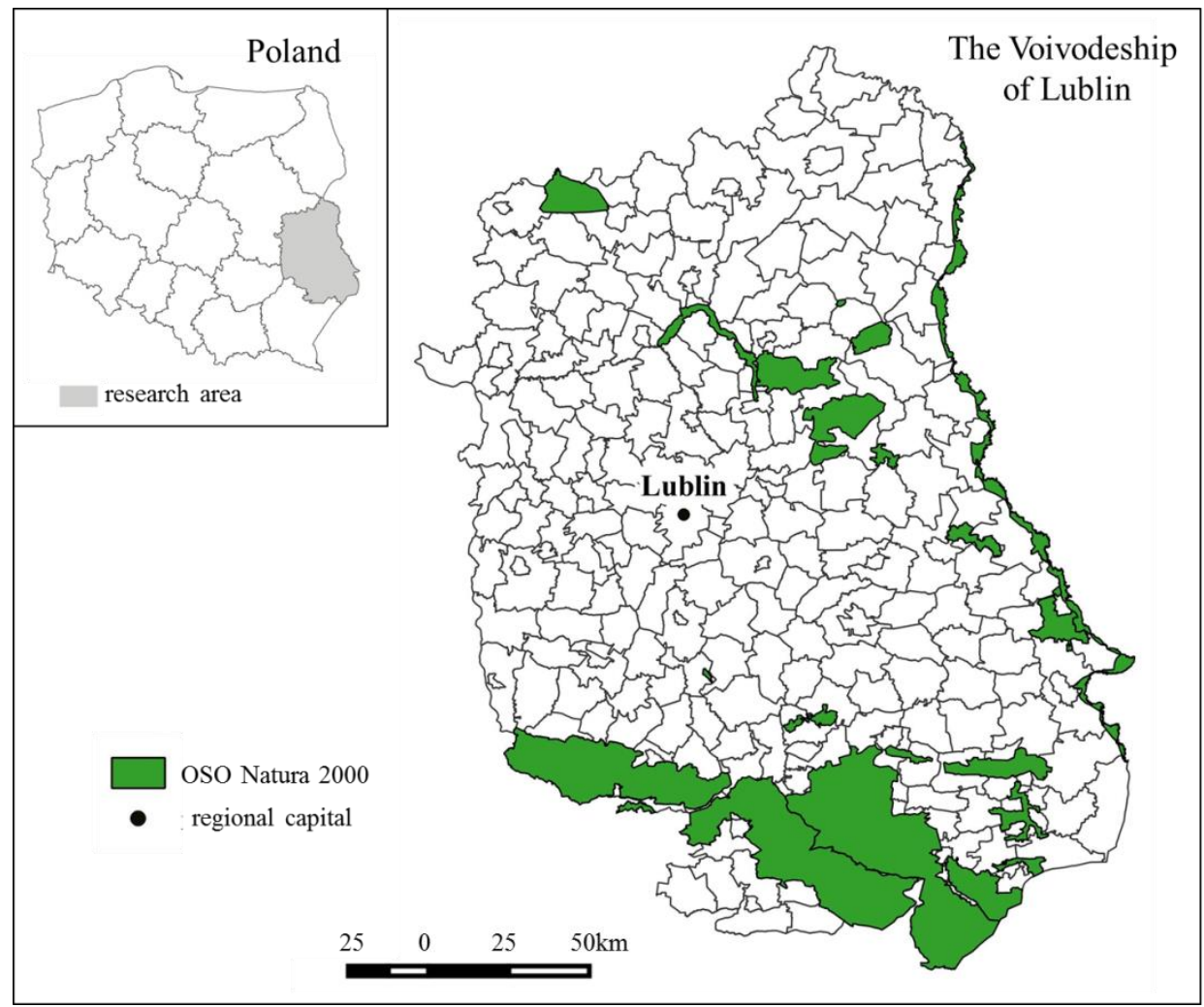

Figure 1. Map of the research area

\section{METHODS}

Both quantitative and qualitative methods were implemented. Such a mix allows to describe tourism infrastructure of SPAs precisely. Quantitative methods included analysis of statistical databases obtained from: Central Statistical Office of Poland, Provincial Agriculture Advisory Centre in Lublin and Polish Tourist Organisation. Basic information about SPAs such as site's area (ha), ecological information, site protection status and relation with other sites came from Standard Data Forms Natura 2000. All available digital and paper maps that cover SPAs in the Voivodeship of Lublin were also used (Table 1).

As existing statistical datasets lack information on food and beverage, these data were collected personally in the field. The same applies to information signboards and signposts. The fieldworks were conducted in 2014, only for selected areas (8 SPAs). Inventarisation include both the areas and adjacent villages.

The existing materials and planning documents on the researched areas, including informational and promotional materials were also reviewed. In addition, the author have participated in nature tours within SPAs of the Voivodeship of Lublin.

The following indicators has been used in the study: the density of food and beverage facilities (number of restaurants, bars, food stores), the density of transport facilities (length of basic transport routes and hiking trails, number of car parks), the density of supporting facilities (field information and specialized facilities) per 1000 ha. Due lack of detailed data on accommodation facilities of some areas, the accommodation density was calculated not for SPA's themselves, but for municipalities that cover the area. The same applies to tourist information centers. 
Table 1. Source of data occurring in the area of research

\begin{tabular}{|l|l|l|}
\hline \multicolumn{1}{|c|}{ Tourist infrastructure } & \multicolumn{1}{c|}{ Inventirized objects } & \multicolumn{1}{c|}{ Source of the data } \\
\hline accommodation & $\begin{array}{l}\text { collective tourist } \\
\text { accommodation } \\
\text { establishments }\end{array}$ & Central Statistical Office of Poland \\
\cline { 2 - 3 } & farm tourism household & $\begin{array}{l}\text { Provincial Agriculture Advisory } \\
\text { Centre }\end{array}$ \\
\hline food and beverage facilities & restaurants, bars, food stores & fieldwork ( inventarisation) \\
\hline transport & basic transport routes & Central Statistical Office of Poland \\
\cline { 2 - 3 } & length of tourist trails & digital and paper maps \\
\cline { 2 - 3 } & car parks & digital and paper maps \\
\hline \multirow{2}{*}{ supporting facilities } & tourist information center & Polish Tourist Organisation \\
\cline { 2 - 3 } & marking areas & fieldwork (inventorisation) \\
\cline { 2 - 3 } & infrastructure specialist & digital and paper maps \\
\hline
\end{tabular}

\section{RESULTS}

\section{Accommodation facilities}

Only collective tourist accommodation establishments and farm tourism households have been included due to lack of other data. According to the data of Central Statistical Office of Poland and Provincial Agriculture Advisory Centre 252 objects of accommodation exist in municipalities that cover SPAs of the Voivodeship of Lublin. These were 214 collective tourist accommodation establishments and 38 farm tourism households of various standards. According to Central Statistical Office of Poland some of the researched municipalities don't have accommodation facilities.

Upper Łabuńka Valley (0,61 objects of accommodation/1000ha) and Roztocze $(0,46$ objects of accommodation/1000ha) have well developed accommodation facilities. In the first case this phenomenon is spatially conditioned, because the SPA is situated next to one of the main tourist attractions of the Voivodeship of Lublin, the town of Zamość. It should be taken in mind, that the accommodation facilities in Zamość are mainly used by people that visit the city, not the protected natural area. The majority of visitors in Zamość is likely to remain unconscious of its presence. A different situation can be observed in Roztocze. As the SPA is at the same time the national park, the accommodation that is widely used by nature tourists developed well before establishing of SPA. The areas has the biggest number of farm tourism households (21 objects of accommodation) among research municipalities. This type of accommodation is well suited to natural tourism, because the owners of farm tourism households connect agricultural business with work in tourism and respect local traditions.

In terms of accommodation, the third developed Natura 2000 area is the Middle Bug River Valley $(0,24$ objects of accommodation/1000ha). Collective tourist accommodation establishments as hotels, campings, and tourists resorts dominate in the area, which is popular leisure destination. Beautiful and wild Bug River offers wonderful conditions for canoeing and rafting hence collective tourist accommodation establishments are numerous, they can be used by organized groups of canoeists.

It the other research municipalities number of accommodation facilities is smaller (from 0,01 to 0,19 objects of accommodation/1000ha). According to the Central Statistical Office of Poland, nine municipalities that cover two SPAs areas (Uroczysko 
Bridges-Zahajki and Upper Huczwa River Catchment) don't have accommodation facilities.

\section{Food and beverage facilities}

Food and beverage facilities complete tourist accommodation and they are used directly by tourists. They include typical eating places (restaurants, bars and permanent gastronomic point) but also food stores. In Poland, the restaurant facilities are relatively underdeveloped, especially in rural areas. This is cause by the lack of tradition of eating out, complicated legislation and relatively high maintenance costs. Consequently the majority of restaurants and bars are the part of the accommodation facilities. The most popular food and beverage facilities are chains of grocery shops and small supermarkets. On the selected 8 SPAs 66 objects of food and beverage were identified. They belong to three categories: restaurants (7), bars (7) and food stores (52) (Table 2). Despite the scarcity of gastronomic points, wide availability of food stores makes food and beverages facilities satisfactory for nature tourists. An important aspect of nature tourism are often long and all-day trips when bringing a packed lunch is necessary. Besides, farm tourism households and other objects of accommodation are equipped with a kitchen or kitchen annexe where it is possible to prepare a meal. It is sufficient for individual tourists. In the summer season tourists flow is followed by opening seasonal food stalls, sales counters and foodtrucks, especially in towns of near the "mainstream" tourism attractions, including some beaches adjacent to water areas that are protected as SPAs (Nieliska Refuge).

Table 2. Density of food and beverage facilities on the selected 8 SPAs

\begin{tabular}{|l|c|c|c|c|}
\hline $\begin{array}{c}\text { Name of Special Protection } \\
\text { Area for birds }\end{array}$ & Restaurants & Bars & Food stores & $\begin{array}{c}\text { Density of food and } \\
\text { beverage/ 1000 ha }\end{array}$ \\
\hline Podedwórze Reservoir & 1 & 1 & 8 & 35,2 \\
\hline Szyszła Valley & 0 & 1 & 6 & 2,7 \\
\hline Upper Labuńka Valley & 1 & 0 & 4 & 2,6 \\
\hline Nieliska Refuge & 2 & 2 & 3 & 2,2 \\
\hline Tyśmienica Valley & 0 & 1 & 11 & 1,6 \\
\hline Sołokija Valley & 2 & 2 & 13 & 1,2 \\
\hline Tyszowiecka Refuge & 1 & 0 & 5 & 0,5 \\
\hline Uroczysko Bridges-Zahajki & 0 & 0 & 2 & 0,4 \\
\hline
\end{tabular}

\section{Transport facilities}

The transport facilities enable the comfort of travel to destination and make visiting Natura 2000 areas more simple. In this study transport facilities include basic transport routes (roads, railways) and hiking trails, including educational trail and car parks.

The general transport network of the region is quite good but the Voivodeship of Lublin lacks of highways. The public transport is widely available. A tourist can travel by bus to all SPAs areas and by train to some of them. However, the journey can be long and exhausted because some buses run infrequently. Within the studied areas local roads dominate. They are usually rough, with some remaining unpaved.

The accessibility of SPAs is improved by the complex network of tourist trails: hiking, bike, horse and water trails (including canoe trails). Their main function is to facilitate hiking and at the same time to keep the tourists away from the areas that should remain untouched. They aim to reduce tourists' activity in the most valuable areas and to distribute them to less popular locations. $2587,5 \mathrm{~km}$ of trails is marked within 
SPAs, including $1183,5 \mathrm{~km}$ of bike trails, $936 \mathrm{~km}$ of hiking trails, $364 \mathrm{~km}$ of water trails and $104 \mathrm{~km}$ of horse trails.

The greatest density of tourist trails were identified within SPAs: Podedwórze Reservoir, Middle Bug River Valley, Roztocze, Polesie, Parczew Forest and Solska Backwoods. High rates of trails density in SPA Podedwórze Reservoir results from the small size of the area (283,7 ha), the reservoir is surrounded by the bike trail. Other mentioned SPAs are much bigger (from 15000 to $100000 \mathrm{ha}$ ) and they are well-known tourist attractions of the Voivodeship of Lublin. As in the case of accommodation, the interference with National Parks (Roztocze and Polesie SPAs) result in well-developed infrastructure.

The rest of the analysed areas characterizes themselves by low density of tourist trails. Here, bike trails dominate (Figure 2), but hiking trails are nor very common. There are no horse and water trails. The poor development of trails can be associated with: low natural or cultural values and lack of famous tourist attractions nearby Natura 2000 area. Moreover, some SPAs include the private breeding pond which impede development of tourism infrastructure (Upper Łabuńka Valley, Sołokija Valley and Tyśmienica Valley). Three research areas (Szyszła Valley, Storks Pond, Upper Huczwa River Catchment) don't have designated trails.

The educational trails complement the network of tourist trails. They can partly or completely double as tourist trails, or they can be marked separately. 117,5 km of educational trails has been identified within SPAs Polesie $(0,92 \mathrm{~km}$ educational trails/1000ha) and Roztocze $(0,87 \mathrm{~km}$ educational trails/1000ha), thus National Parks, mark out with their highest density.

Transport facilities include also car parks. Their inventorisation is difficult because car parks are poorly marked on the tourist maps and on site. Furthermore, it is problematic to assess the scale of their use by tourists and local people. Nieliska Refuge stands out with the numerous car parks, where one car park accounts for 1500 ha. In other research areas the situation is as follow: in Parczew Forest one car park accounts for 2700 ha, but in Polesie one car park accounts for 3500 ha. Tourists visiting the Natura 2000 areas often used informal car parks.

Some trails are equipped with additional tourist infrastructure (viewpoints, watchtowers, fireplaces), which are describe in the next part of the article.

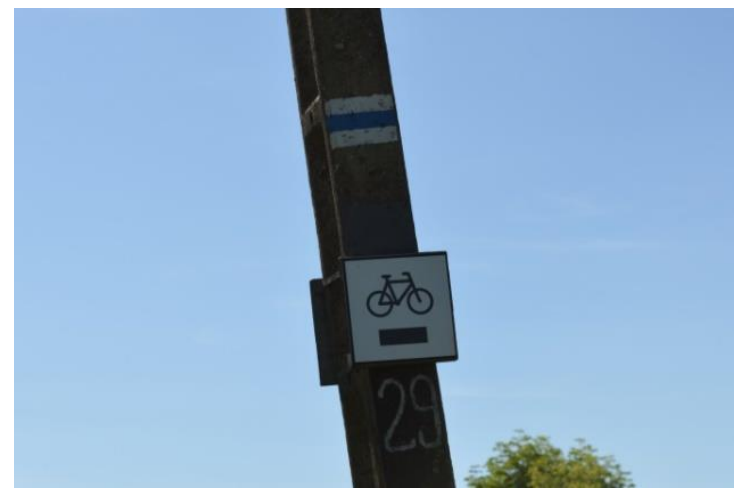

Figure 2. Marking of cycling and hiking trails in Nieliska Refuge, May 2015 (Photo by M. Kordowska)

\section{Supporting facilities}

The supporting facilities include information infrastructure (tourist information centers, signboards), specialized facilities (watchtowers, tourist sheds, viewpoints) and rental place (bikes, canoes).

The tourist information centers are located in several municipalities which cover the researched SPAs. Tourists can find them only in the major tourist destinations. Moreover, the tourist information only offer the information about popular sights 
and places. There is a significant lack of information about the nearby protected areas except the tourist information in the region of Roztocze.

The Natura 2000 areas are equipped with signboards and signposts. They inform on trail's length, number of stops and level of difficulty, often a map is provided. The signposts usually show the direction of futher visit (Figure 3). The best marked areas are Nieliska Refuge (1,91 information infrastructure/1000ha), Szyszła Valley (0,78 information infrastructure/1000ha) and Tyśmienica Valley $(0,68$ information infrastructure /1000ha).

The specialize facilities are used by nature tourist depending on their needs. Bird-watchers find the watchtowers to be useful, but plant lovers are interested in footbridges that facilitate exploring species-rich wetlands. The watchtowers are usually several meters high wooden constructions (Figure 4). Within 20 SPAs 22 watchtowers were inventoried. Additionally the birds, other animals and the landscape can be admired from the marked viewpoints. According to the paper maps 17 such a points exist within researched SPAs. These place can be developed developed by installation of benches and stationary binoculars. Along hiking trails tourist sheds are located 51 objects in total.

8 SPAs don't have specialized facilities. These are areas which have never been protected and are remoted from tourist attractions. They are well-known of their rich avifauna and development of birdwatching and related infrastructure is advisable.

The described objects are usually made of wood. Changing environmental factors leads to their damage, so they require regular maintenance. Sometimes these objects are devastated by hooligans. Additionally, rental places (bikes, canoes, pedalos) are located within SPAs, particularly around lakes and water reservoirs. They occur in small numbers Roztocze, Nieliska Refuge and in the Middle Bug River Valley.

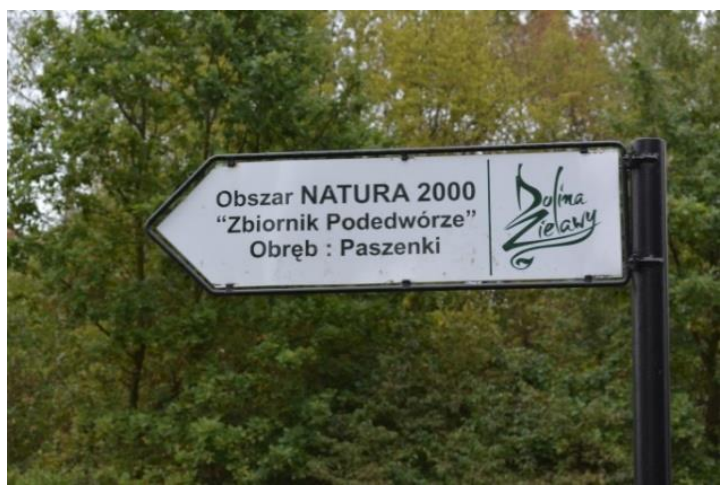

Figure 3. Singnpost in the region of Podedwórze Reservoir, September 2015 (Photos by M. Kordowska)

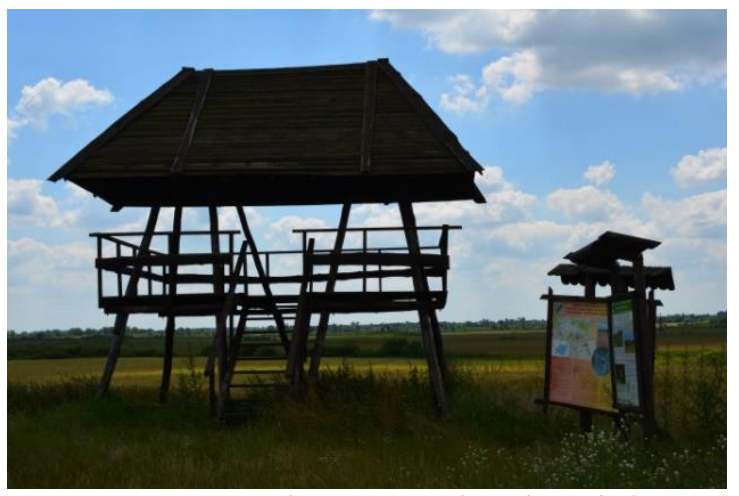

Figure 4. Watchtowers on the edge Chełm Calcareous Marshes, July 2014

\section{CONCLUSIONS}

High environmental values of SPAs favour nature tourism development. However, the resources are not used efficiently. It is manifested by the scarcity of agrotourism, low quantity of gastronomy facilities and bad technical state of some specialized facilities. The main reason of such a situation is the lack of knowledge on values of Natura 2000 area. Their economic development is commonly perceived as impossible. The system of management of protected areas in Poland is also pretty 
complicated, as it is dispersed on several administrative levels. This causes additional communication problems between local government officials, tourists and owners.

The best way of sustainable development of tourism in protected areas is proper management. The development of equipped natural trails should be supported. Even the best idea for development and planning of tourism infrastructure could be not totally safe for environment. High number of tourist would increase degradation of breeding birds areas. The good idea is to prepare special educational stops with pictures and drawings on tourists trails. This option affect people attitude to nature more efficiently simple information on prohibited activities [9].

Moreover, it is important to plan tourism development and infrastructure having in mind tourists behaviour, spatial conditions and natural carrying capacity. The situation where one area is overexploited and other underdeveloped should not occur.

\section{REFERENCES}

[1] The Act of 16 April 2004 on Nature Protection (consolidated text Dz.U. 2015, item 1651)

[2] Bastian O., The role of biodiversity in supporting ecosystem services in Natura 2000 sites, Ecological Indicators, vol.24, pp.8-9, 2014.

[3] Priskin J. Assessment of Natural Resources for Nature-based Tourism: the Case of the Central Coast Region of Western, Tourism Management, vol 22(6), pp 637-648, 2001.

[4] Dudek A., Kowalczyk A. Turystyka na obszarach chronionych - szanse i zagrożenia, Prace i Studia Geograficzne, Warszawa, vol. 32, pp 117-140, 2003.

[5] Kowalczyk A. Turystyka zrównoważona, PWN, Warszawa, pp. 10, 2010.

[6] Goodwin H. In Pursuit of Ecotourism, Biodiversity and Conservation, vol 5(3), pp 277-291, 1996.

[7] Poskrobko B. Zarządzanie turystyką na obszarach przyrodniczo cennych, Wyższa Szkoła Ekonomiczna w Białymstoku, Białystok, pp. 96-97, 2005.

[8] Kondracki J. Geografia regionalna Polski. PWN, Warszawa, pp. 35, 2002

[9] Symonides E. Ochrona przyrody. Wydawnictwo Uniwersytetu Warszawskiego, Warszawa, pp. 668, 2008. 